\title{
Agromorphological characterization of Sesamum radiatum (Schum. and Thonn.), a neglected and underutilized species of traditional leafy vegetable of great importance in Benin
}

\author{
Adéoti K. ${ }^{1}$, Dansi A. ${ }^{2,3 \star}$, Ahoton L. ${ }^{4}$, Vodouhè R. ${ }^{5}$, Ahohuendo B. C. ${ }^{4}$, Rival A. ${ }^{6}$ and Sanni A. ${ }^{1}$ \\ ${ }^{1}$ Laboratory of Biochemistry and Molecular Biology, Faculty of Sciences and Technology (FAST), \\ University of Abomey-Calavi (UAC), Cotonou, Republic of Benin. \\ ${ }^{2}$ Laboratory of Agricultural Biodiversity and Tropical Plant Breeding, Faculty of Sciences and Technology (FAST), \\ University of Abomey-Calavi (UAC), 071BP28, Cotonou, Republic of Benin. \\ ${ }^{3}$ Crop, Aromatic and Medicinal Plant Biodiversity Research and Development Institute (IRDCAM), 071 BP 28, \\ Cotonou, Republic of Benin. \\ ${ }^{4}$ Department of Plant Production, Faculty of Agricultural Sciences (FSA), University of Abomey-Calavi (UAC), \\ BP 526 Cotonou, Republic of Benin. \\ ${ }^{5}$ Bioversity International, Office of West and Central Africa, 08 BP 0931, Cotonou, Republic of Benin. \\ ${ }^{6}$ Cirad-BioS, UMR DIAPC, Centre IRD. F-34394 Montpellier Cedex5, France.
}

Accepted 14 May, 2012

\begin{abstract}
Sesamum radiatum (Schum. and Thonn) is a traditional leafy vegetable of national importance in Benin. Although, it is cultivated and consumed in many regions of the country, it is still unfortunately neglected by scientific research. In order to fill in the knowledge gaps necessary for its varietal improvement, 16 accessions collected from different agro-ecological zones were characterized using 16 quantitative morphological traits. A significant variability was found among the accessions. Day to flowering, day to fruiting, total biomass, plant height, noose diameter, number of fruits per plant and number of seeds per fruit were some of the most discriminating parameters. Multivariate analysis (principal component analysis and cluster analysis) revealed four distinct agro-morphological groups of varying performance which will be highly useful in varietal improvement. Correlation analyses between descriptors revealed uniquely desired positive and negative relationships hence, indicating predictable success for eventual breeding program. To further investigate the genetic basis of the phenotypic diversity revealed among $S$. radiatum accessions, the use of molecular markers such as amplified fragment length polymorphisms (AFLPs) is recommended.
\end{abstract}

Key words: Benin, Sesamum radiatum, diversity, morphological characterization, leafy vegetable.

\section{INTRODUCTION}

Throughout the tropical world and particularly, in West Africa, a large number of traditional leafy vegetables (TLVs) have long been known and reported to play important roles in food security for people living in both

\footnotetext{
${ }^{*}$ Corresponding author. E-mail: adansi2001@gmail.com.
}

rural and urban areas (Maundu et al., 1999; Schippers, 2002; Abukutsa, 2007; Francisca and Eyzaguirre, 2007). TLVs are rich in vitamins (especially A, B and C), minerals, fibres, carbohydrates and proteins and some even possess medicinal properties (Almekinders and de Boef, 2000; Schippers, 2002; Grubben and Denton, 2004; Dansi et al., 2008). They represent cheap but quality nutrition for large segments of the populations and 


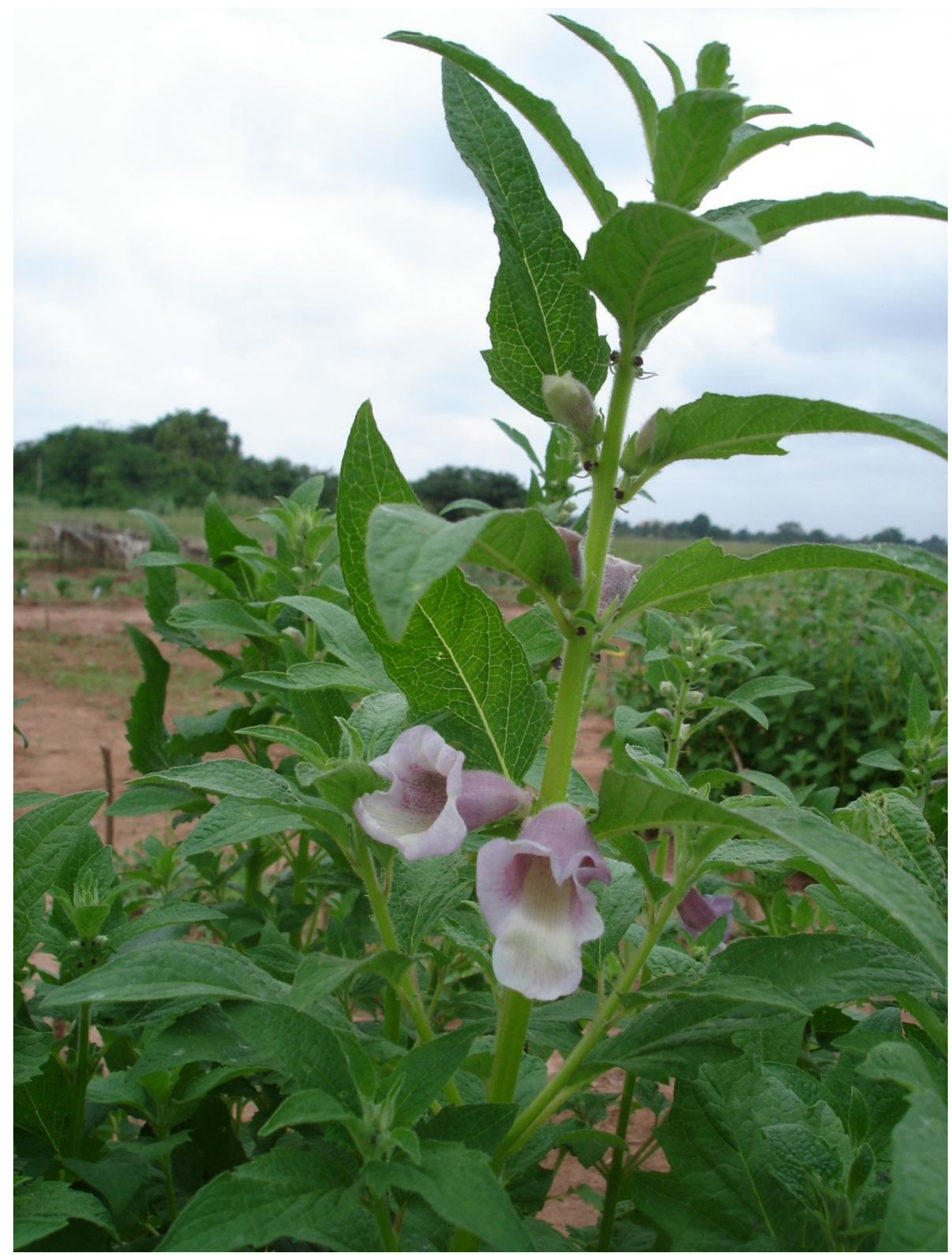

Figure 1. Vegetative aerial part of a Sesamum radiatum plant showing some leave, stem and flower details.

offer an opportunity for improving nutritional status of many families (Chweya and Eyzaguirre, 1999). In many West Africa countries, leafy vegetables are reported to account for 50 to $100 \%$ of rural households' income (Mbaye and Moustier, 2000; Diouf et al., 2007) hence, contributing to food security and poverty alleviation.

Recent ethnobotanical investigation of TLVs consumed in Benin revealed 187 species among which Sesamum radiatum (Adéoti et al., 2009). S. radiatum (Figure 1) is wildly consumed throughout Benin as slimy and nutraceutical vegetable. It is antibiotic and known to treat or prevent hepatic insufficiencies (Shittu et al., 2006). The leaves are also used for treating various sickness including stomach ailments, catarrh, eye pains, bruises and erupted skins (Ogunlesi et al., 2010). Leaves extract was found to have significant myorelaxant effect in 
Table 1. List of ecotypes and collecting site (N: North; S: South).

\begin{tabular}{llll}
\hline Ecotypes & Status & Collecting sites & Districts \\
\hline S5 & Wild & Atchonsa & Bonou \\
S6 & Wild & Kodé & Adjohoun \\
S7 & Wild & Yoko & Sakété \\
S8 & Wild & Hounti & Lokossa \\
S12 & Wild & Koudokpoe & Zê \\
S13 & Wild & Foli & Za-Kpota \\
S14 & Wild & Sokounhoue & Djakotomè \\
S15 & Wild & Kessounou & Dangbo \\
S16 & Wild & Issaba & Pobè \\
N1 & Cultivated & Gbetebou & Tchaourou \\
N2 & Cultivated & Toume & Sinendé \\
N3 & Cultivated & Saoré & Bembéréké \\
N4 & Cultivated & Goro & Tchaourou \\
N10 & Cultivated & Koutagou & Boukoumbé \\
N11 & Cultivated & Bellefoungou & Djougou \\
N9 & Cultivated & Kotiakou & Tanguieta \\
\hline
\end{tabular}

guinea-pig thus, supporting the traditional use of the fresh leaves for treating cardiovascular diseases in Cote d'Ivoire (Konan et al., 2006, 2008; Kimiywe et al., 2007). In Western Nigeria, the leaves are used in correcting male sterility by enhancing sperm count and its scientific evidences have been recently provided (Shittu et al., 2007; Ogunlesi et al., 2010). Its cultivation in Benin is the prerogative of women and because of its high market demand appears as one of the vegetables that greatly contribute to household income in rural areas. With regard to the first millennium development goal which calls to combat extreme poverty and hunger, $S$. radiatum is one of the species to consider for promotion in the category of leafy vegetables in the agricultural sector. Despite its nutritional, medicinal and economic importance, the species has been poorly investigated and is currently classified among the so called neglected and under-utilized species (NUS) of Benin (Dansi et al., 2012).

The development of an economically profitable production of any plant species like $S$. radiatum undoubtedly requires the use of improved high yielding varieties. To facilitate breeding efforts, characterisation of available germplasm is a necessary first step since it especially, benefits a plant breeder in choosing proper parental materials (Cilliers and Swanevelder, 2003; Sarutayophat et al., 2007). Also, the knowledge about interrelationships among descriptors (characteristics), from a plant breeder's perspective aid in the selection of superior genotypes from the breeding population and is important in planning and evaluating breeding programmes (Sheela and Gopalan, 2006).

The objectives of this study were to characterize and study the diversity among local ecotypes of $S$. radiatum using agro-morphological descriptors and to study the interrelationship among descriptors used in order to identify outstanding accessions which could be involved in national breeding programs for the benefit of both producers and consumers.

\section{MATERIALS AND METHODS}

\begin{abstract}
The study area
Plant accessions were originated from different regions of the Republic of Benin situated in West Africa, between latitudes 6 $6^{\circ} 10^{\prime} \mathrm{N}$ and $12^{\circ} 25^{\prime} \mathrm{N}$ and longitudes $0^{\circ} 45^{\prime} \mathrm{E}$ and $3^{\circ} 55^{\prime} \mathrm{E}$ (Adam and Boko, 1993). The country covers a total land area of $112,622 \mathrm{~km}^{2}$ with a population estimated at about 7 millions (Adomou, 2005). It is partitioned into 12 departments inhabited by 29 ethnic groups (Adam and Boko, 1993). The south and the centre are relatively humid agro-ecological zones with two rainy seasons and mean annual rainfall of $1500 \mathrm{~mm} / \mathrm{year}$ (Adam and Boko, 1993). The North is situated in arid and semi-arid agro-ecological zones characterized by unpredictable and irregular rainfall oscillating between 800 and $950 \mathrm{~mm} / \mathrm{year}$ with only one rainy season. Mean annual temperatures range from 26 to $28^{\circ} \mathrm{C}$ and may exceptionally reach 35 to $40^{\circ} \mathrm{C}$ in the far Northern localities (Adomou, 2005; Akoègninou et al., 2006). The country has about 2,807 plant species (Akoègninou et al., 2006). Vegetation types are semi deciduous forest (South), woodland and savannah woodland (centre East and Northeast), dry semi deciduous forest (centre West and South of Northwest) and tree and shrub savannahs (far north). The experiment was conducted at the station of the International Institute of Tropical Agriculture (IITA) based in Cotonou (South of Benin).
\end{abstract}

\section{Plant material, experimental design and data collection}

Sixteen accessions of local ecotypes collected in the wild and in the cultivated fields were studied (Table 1). Seeds were first sown in polythene bags and after germination; ensuing seedlings were transplanted at the four-leaf stage to $3 \times 2 \mathrm{~m}$ plots in a completely randomized block design with four replicates, at a spacing of $50 \mathrm{~cm}$ between rows and $30 \mathrm{~cm}$ within rows as per IPGRI (2001). The field, primarily five years fallow was organic manure-fed. Sixteen (16) qualitative and quantitative parameters of floral and vegetative development, leaf and seed production were studied. These were: days to flowering, total biomass, plant height, node diameter, number of ramification, height of the first branch, leaf length, leaf width, petiole length, days to fruiting, number of fruits per plant, fruit length, fruit width, number of seeds per fruit, thousand seeds weight and seed germination rate. These parameters were measured and data collected as specified in Table 2 from twelve weeks after sowing on five healthy individual plants randomly selected from each of the accessions per repetition following IPGRI (2001).

\section{Data analysis}

Collected data was subjected to the one-way analysis of variance using Statistical Analysis System (SAS, 1999) software package and the Student and Newman-Keuls' test was used to separate the treatment means. Using the same software, pairwise distances between accessions were computed and the similarity matrix generated was used to perform a Principal Component Analysis (PCA) and to design a dendrogram using UPGMA cluster analysis (Sneath and Sokal, 1973; Swofford and Olsen, 1990). Computation 
Table 2. Quantitative estimation of morphological traits of Sesamum radiatum.

\begin{tabular}{lll}
\hline Characters & Codes & Technique of measurement \\
\hline Plant height & PH & Length from soil to the tip of terminal flower head \\
Leaf length & LL & Distance between the leaf tip and base measured on the third fully opened leaf from the tip \\
Leaf width & LW & Width of the broadest portion of the third fully opened leaf from tip measured \\
Petiole length & PL & Measured from main stem to leaf base of the third fully opened leaf from the tip \\
Noose diameter & ND & An horizontal measure of transition zone between root and stem \\
Number of ramifications & NR & Count of the total number of ramifications inserted on the stem from soil to the top of plant \\
Height of first ramification & HFR & Length from soil to the knot of the first ramification \\
Number of fruits per plant & NFP & Count of the total number of mature fruits obtained from one plant \\
Thousand seeds weight & TSW & Weight of thousand good seeds measured \\
Total biomass & TBIO & Weight of the total leaves collected from one plant \\
Number of seeds per fruit & NSF & Count of the number of seeds obtained per capsule \\
Fruit length & FL & Measured from the base of fruit to the tip of fruit' horn \\
Germination rate & SGR & Total number of germinated seeds out of the total number sown \\
Fruit width & FW & Width of the broadest portion of mature seed \\
Days to flowering & DTF & Determined by noting the number of days from sowing that $50 \%$ of plants had at least one flower \\
Days to fruiting & DFR & Determined by noting the number of days that $50 \%$ of plants had at least one fruit \\
\hline
\end{tabular}

Table 3. Descriptive statistics of morphological variables measured within accessions of Sesamum radiatum collected in Benin.

\begin{tabular}{lccccc}
\hline Characters & Minimum & Maximum & Mean & Standard deviation & Coefficient of variation \\
\hline Plant height & 55 & 141 & 106.79 & 14.97 & 0.140 \\
Leaf length & 1.35 & 4.35 & 2.82 & 0.58 & 0.206 \\
Leaf width & 0.3 & 0.8 & 0.54 & 0.13 & 0.241 \\
Petiole length & 0.1 & 0.2 & 0.14 & 0.04 & 0.286 \\
Noose diameter & 11 & 23 & 17.09 & 2.39 & 0.140 \\
Number of ramifications & 10 & 36 & 22.20 & 4.92 & 0.222 \\
Height of the first ramification & 2 & 4 & 3.30 & 0.66 & 0.200 \\
Number of fruits per plant & 4 & 567 & 228.74 & 129.00 & 0.564 \\
Thousand seeds weight & 2.21 & 4.1 & 2.78 & 0.58 & 0.209 \\
Total biomass & 16.5 & 450 & 171.85 & 112.74 & 0.656 \\
Number of seeds per fruit & 52 & 108 & 78.25 & 12.32 & 0.157 \\
Fruit length & 2.4 & 3.4 & 2.86 & 0.27 & 0.094 \\
Seed germination rate & 0.1 & 0.6 & 0.27 & 0.13 & 0.481 \\
Fruit width & 0.7 & 0.9 & 0.76 & 0.08 & 0.105 \\
Days to flowering & 18 & 62 & 38.19 & 15.95 & 0.418 \\
Days to fruiting & 26 & 72 & 46.94 & 17.03 & 0.363 \\
\hline
\end{tabular}

of Pearson coefficients of correlation among descriptors was also done using the same software.

\section{RESULTS AND DISCUSSION}

Descriptive values (maximum, minimum, mean, standard deviation and coefficient of variation) of the measured quantitative parameters are compiled in Table 3. Data obtained revealed that Coefficients of variation (CV) varied from $9.4 \%$ (fruit length) to $65.6 \%$ (biomass). The most varying characters as shown by the $\mathrm{CV}$ values were: number of fruit $(56.4 \%)$, germination rate $(48.1 \%)$, flowering time $(41.8 \%)$, fruiting time $(36.3 \%)$, petiole length $(28.6 \%)$, leaf width $(24.1 \%)$, number of ramifications $(22.2 \%)$, and weight of 1,000 seeds $(20.9 \%)$, leaf length $(20.6 \%)$, and height of the first ramification $(20 \%)$. Characters showing weak variation included plant height, noose diameter, number of seeds per fruit, fruit width and fruit length. These very different CV measured for each character is the reflection of some 
Table 4. Comparison of means using the test of Student-Newman-Keuls on morphological variables measured in accessions of Sesamum radiatum collected in Benin.

\begin{tabular}{lcccc}
\hline Accessions & Height $(\mathbf{c m})$ & Leafy length (cm) & Leafy width (cm) & Total biomass (g) \\
\hline N1 & $120.20^{\mathrm{a}}$ & $03.52^{\mathrm{ab}}$ & $0.68^{\mathrm{a}}$ & $225.34^{\mathrm{abc}}$ \\
N2 & $103.20^{\mathrm{abc}}$ & $02.93^{\mathrm{bcd}}$ & $0.63^{\mathrm{a}}$ & $338.56^{\mathrm{a}}$ \\
N3 & $95.60^{\mathrm{bc}}$ & $03.24^{\mathrm{bc}}$ & $0.70^{\mathrm{a}}$ & $199.24^{\mathrm{abc}}$ \\
N4 & $100.80^{\mathrm{abc}}$ & $03.12^{\mathrm{bcd}}$ & $0.63^{\mathrm{a}}$ & $217.00^{\mathrm{abc}}$ \\
S5 & $93.80^{\mathrm{bc}}$ & $01.94^{\mathrm{a}}$ & $0.36^{\mathrm{cd}}$ & $26.52^{\mathrm{d}}$ \\
S6 & $107.60^{\mathrm{abc}}$ & $02.13^{\mathrm{ef}}$ & $0.34^{\mathrm{d}}$ & $55.48^{\mathrm{cd}}$ \\
S7 & $113.40^{\mathrm{ab}}$ & $2.52^{\mathrm{de}}$ & $0.42^{\mathrm{cd}}$ & $127.28^{\mathrm{bcd}}$ \\
S8 & $112.20^{\mathrm{ab}}$ & $02.98^{\mathrm{bcd}}$ & $0.46^{\mathrm{bc}}$ & $114.40^{\mathrm{bcd}}$ \\
N9 & $94.00^{\mathrm{bc}}$ & $03.07^{\mathrm{bcd}}$ & $0.56^{\mathrm{ab}}$ & $193.36^{\mathrm{abcd}}$ \\
N10 & $112.00^{\mathrm{ab}}$ & $02.97^{\mathrm{bcd}}$ & $0.59^{\mathrm{ab}}$ & $309.18^{\mathrm{a}}$ \\
N11 & $112.20^{\mathrm{ab}}$ & $03.76^{\mathrm{a}}$ & $0.68^{\mathrm{a}}$ & $267.54^{\mathrm{ab}}$ \\
S12 & $122.60^{\mathrm{a}}$ & $02.84^{\mathrm{cd}}$ & $0.57^{\mathrm{ab}}$ & $187.94^{\mathrm{abcd}}$ \\
S13 & $122.00^{\mathrm{a}}$ & $02.79^{\mathrm{cd}}$ & $0.58^{\mathrm{ab}}$ & $177.32^{\mathrm{abcd}}$ \\
S14 & $84.20^{\mathrm{c}}$ & $01.96^{\mathrm{a}}$ & $0.48^{\mathrm{bc}}$ & $80.56^{\mathrm{cd}}$ \\
S15 & $115.60^{\mathrm{ab}}$ & $02.76^{\mathrm{cd}}$ & $0.42^{\mathrm{cd}}$ & $109.68^{\mathrm{bcd}}$ \\
S16 & $113.20^{\mathrm{ab}}$ & $02.64^{\mathrm{cd}}$ & $0.47^{\mathrm{bc}}$ & $120.28^{\mathrm{bcd}}$ \\
\hline
\end{tabular}

Table 5. Principal component analysis of morphological variables measured in various accessions of Sesamum radiatum collected in Benin.

\begin{tabular}{lccc}
\hline \multirow{2}{*}{ Designation } & \multicolumn{3}{c}{ Eigen vectors } \\
\cline { 2 - 4 } & PC1 & PC2 & PC3 \\
\hline Eigen value & 6.75 & 2.45 & 1.71 \\
Proportion & 39.73 & 14.42 & 10.06 \\
Cumulative & 39.73 & 54.15 & 64.21 \\
\hline
\end{tabular}

level of variability among accessions.

The analysis of variance revealed significant differences between accessions for the plant height $(\mathrm{PH})$, leaf length (LL), leaf width (LW) and total biomass (TBIO). For these four variables taken individually, the Student-Newman-Keuls' tests classified accessions into five to seven groups (Table 4) hence, indicating significant intraspecific diversity. This means that these descriptors are very important in differentiating between the accessions.

The principal component analysis grouped the 16 variables into various components with the first three explaining $64.21 \%$ of the total variation (Table 4). Principal component 1 (PC1) associated with leaf length $(\mathrm{LL})$, leaf width $(\mathrm{LW})$, petiole length $(\mathrm{PL})$, number of fruits (NF), biomass (BIO), number of seed per fruit (NSF), fruit length (FL), fruit width (FW), date to flowering (DTF) and date to fruiting (DFR) accounted for $39.73 \%$ of the total variation (Tables 4 and 5). PC2 consisting mainly of noose diameter (NOD), germination rate (GR) and 1000 seeds weight (TSW) accounted for $18 \%$ of the total variation while PC3 associated with the number of ramifications and the height of the first ramification explained $10.06 \%$ of the total variation (Tables 5 and 6 ). Based on this data, PC1 appears as one of the most important features in leafy vegetable selection which is vegetative vigour (leaf size, total biomass), earliness (date to flowering) and fruiting (date, number per plant, size). This explains why PC1 alone account for about $40 \%$ the total variation. From all the characters, flowering time was found to be the most discriminative parameter differentiating accessions. A relation seems to exist between maturity period and geographical origin. In fact, accessions (N1, N2, N4 and N10) originating from the Northeast were late flowering while accessions (S5, S6, S7) collected from the South showed precocious flowering and those from Northwest and South (N9, S12 and S13) showed an intermediate flowering time. To this regard, the assessment of the influence of the ecology on the reproduction biology of this species is important as such influences have been already reported for many species (Avolio et al., 2011; Bai et al., 2011).

Based on the PC1 and PC2, the sixteen accessions studied were classified into four agromorphological groups (Figure 2) named G1, G2, G3 and G4. The dendrogram (Figure 3 ) was constructed based on the UPGMA cluster analysis also revealed (with $R^{2}=0.53$ ) four groups identical to those obtained with the principal component analysis, hence indicating the reliability of the classification. The four groups obtained have clear different performances (Table 7). Group 1 is early maturing and is characterized by a great number of fruits per plant while Group 4 produces fruits of relatively big size containing several seeds of also big size. Plants of 
Table 6. Eigen vectors and values for the three principal component axes.

\begin{tabular}{lccc}
\hline \multirow{2}{*}{ Characters } & \multicolumn{3}{c}{ Eigen vectors } \\
\cline { 2 - 4 } & PC1 & PC2 & PC3 \\
\hline Plant height & 0.193 & 0.773 & 0.146 \\
Leaf length & 0.817 & 0.176 & -0.152 \\
Leaf width & 0.915 & 0.190 & -0.206 \\
Petiole length & 0.838 & 0.073 & -0.435 \\
Noose diameter & 0.293 & 0.553 & 0.445 \\
Number of ramifications & 0.385 & -0.071 & 0.442 \\
Height of first ramification & -0.116 & 0.340 & 0.610 \\
Number of fruits per plant & -0.690 & -0.162 & -0.058 \\
Thousand seeds weight & 0.378 & -0.415 & -0.061 \\
Total biomass & 0.763 & 0.111 & 0.343 \\
Number of seeds per fruit & 0.643 & -0.493 & -0.230 \\
Fruit length & 0.522 & -0.227 & 0.018 \\
Seed germination rate & 0.437 & -0.609 & 0.477 \\
Fruit width & 0.605 & -0.329 & 0.128 \\
Days to flowering & 0.953 & 0.109 & 0.008 \\
Days to fruiting & 0.949 & 0.116 & 0.002 \\
\hline
\end{tabular}

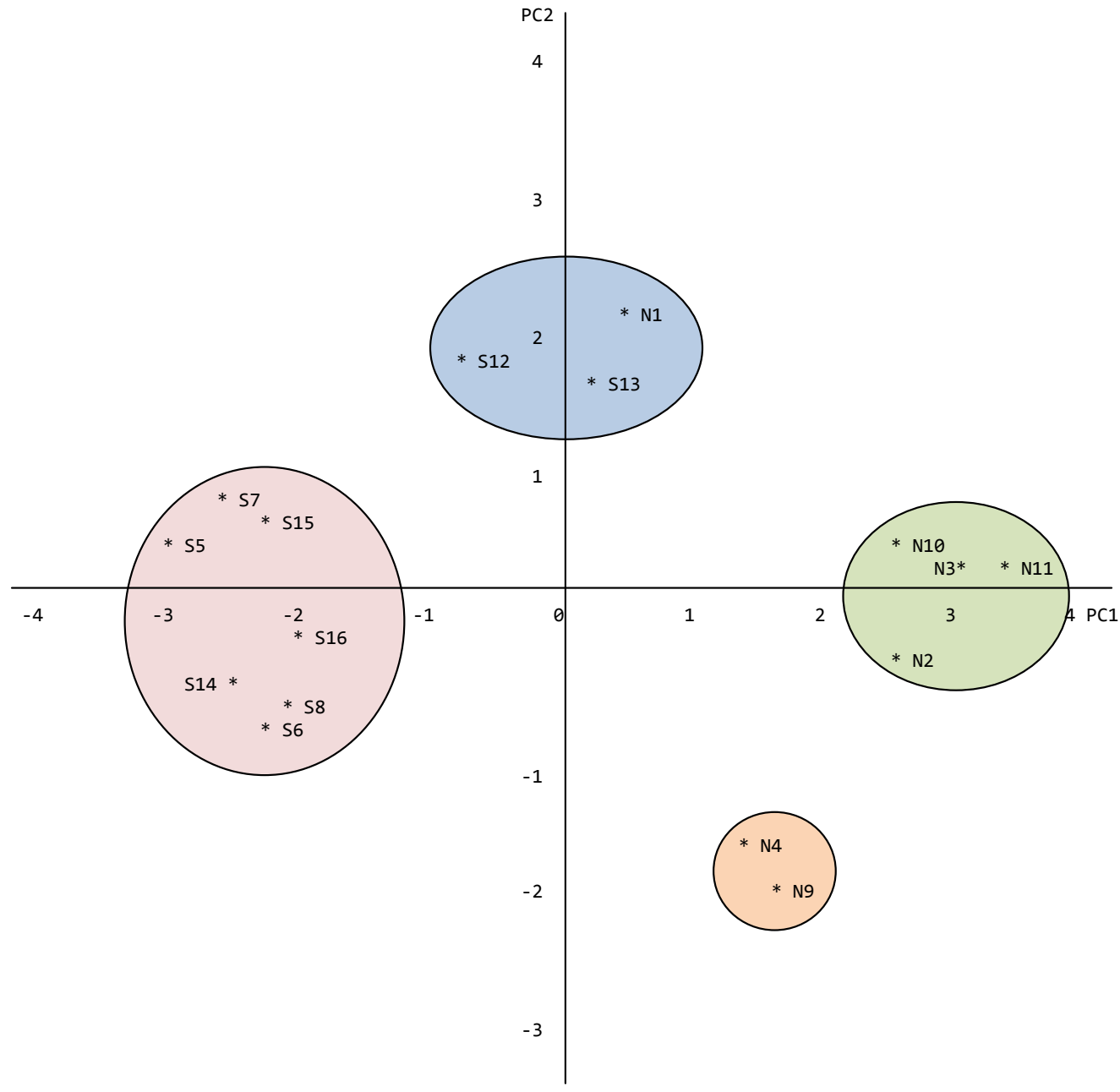

Figure 2. Principal component analysis showing the different grouping of the accessions. 


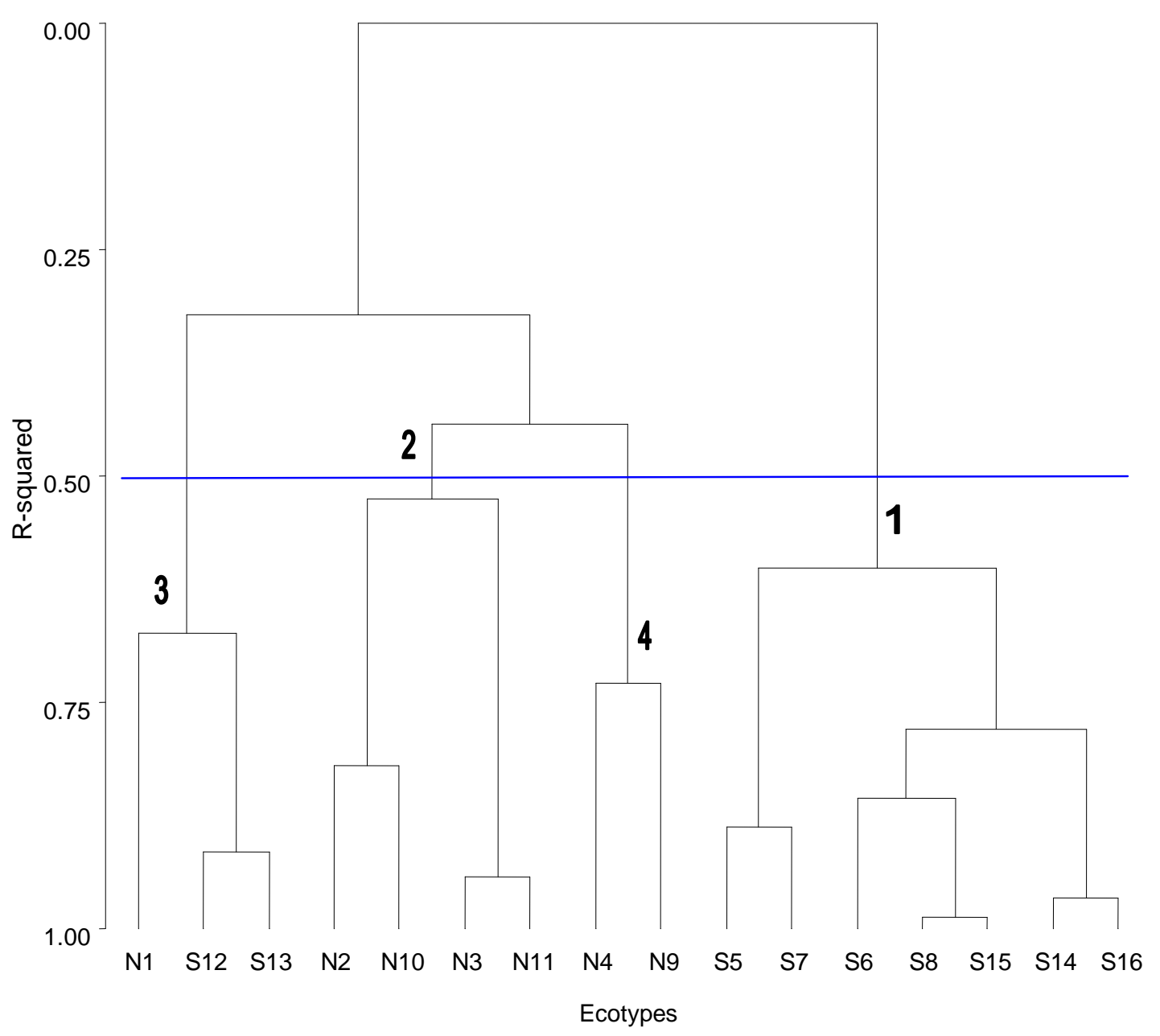

Figure 3. Dendrogram showing the relationship among 16 accessions of Sesamum radiatum collected in Benin using the UPGMA methodology.

Group 2 are vigorous (large sized leaves, many ramifications, relatively big noose diameter), produce important biomass and are late maturing in terms of flowering and fruiting. Group 3 is characterised by a high plant height. With leafy vegetable in general, the desired characters for both producers and consumers include high production of total biomass, late flowering and very good fruit with several seeds (Chattopadhyay et al., 1996; Mih et al., 2008). To this regard, data obtained in this study will be highly useful in developing new varieties of $\mathrm{S}$. radiatum by series of crossing between the different group.

Accessions from the groups G2 and G4 exhibiting the best desirable performances are those collected from the home gardens in the North where the species is mostly cultivated and consumed. This may be the results of many years of morphological selection undertaken by farmers with the aim of getting plants with the potential to attract premium prices in local markets. As reported by Vodouhe et al. (2011), getting better performing varieties has been always one key objective of plant domestication for food purposes.

The correlation matrix between variables (Table 8) indicates positive significant correlations between leaf length and leaf width in one hand and between these two parameters and the total biomass in the other hand. Similarly, day to flowering evolves parallel to day to fruiting and the two are also positively correlated to leaf length, leaf width and total biomass. Contrary to this, the number of fruits per plant is negatively correlated to both leaf length and leaf width.

The same significant negative correlation is observed between the number of fruits per plant and the number of seeds per fruit. In terms of plant breeding, these data clearly indicates that with $S$. radiatum selecting varieties with producers and consumers desired characters as indicated above will easily success. Similar results were reported on Hibiscuss abdariffa and Amaranthus (Diouf et al., 2007), Vernonia amygdalina (Mih et al., 2008) and cowpea (Musvosvi, 2009).

To further investigate the genetic basis of the phenotypic diversity revealed among $S$. radiatum 
Table 7. Numerical classification of morphological variables measured in accessions of Sesamum radiatum collected in Beninand performance of each class.

\begin{tabular}{|c|c|c|c|c|}
\hline \multirow{2}{*}{ Characters } & \multicolumn{4}{|c|}{ Mean value of each class } \\
\hline & Class 1 & Class 2 & Class 3 & Class 4 \\
\hline Plant height (cm) & 105.71 & 105.75 & $121.60^{*}$ & 97.40 \\
\hline Leaf length (cm) & 2.30 & $3.23^{*}$ & 3.05 & 3.10 \\
\hline Leaf breadth (cm) & 0.42 & $0.65^{\star}$ & 0.61 & 0.60 \\
\hline Petiole length (cm) & 0.11 & $0.16^{\star}$ & 0.15 & 0.16 \\
\hline Noose diameter (mm) & 16.91 & $18.20^{*}$ & 17.73 & 16.00 \\
\hline Number of ramification & 21.80 & $25.50^{\star}$ & 19.93 & 21.40 \\
\hline Height of 1 st ramification $(\mathrm{cm})$ & 3.26 & 3.15 & 3.80 & $3.00^{*}$ \\
\hline Number of fruit per plant & $280.57^{*}$ & 137.75 & 199.00 & 278.50 \\
\hline Thousand seeds weight & 2.48 & 2.77 & 2.67 & $3.99^{*}$ \\
\hline Biomass (g) & 105.75 & $256.63^{*}$ & 196.87 & 205.18 \\
\hline Number of seeds/fruit & 71.43 & 88.00 & 72.00 & $92.00^{*}$ \\
\hline Capsule length (cm) & 2.74 & 2.85 & 2.83 & $3.30^{*}$ \\
\hline Rate of germination & 0.22 & $0.38^{*}$ & 0.25 & 0.35 \\
\hline Fruit breadth (cm) & 0.73 & $0.85^{*}$ & 0.70 & 0.80 \\
\hline Days to flowering & $21.29^{*}$ & $56.75^{\star}$ & 46.33 & 48.00 \\
\hline Days to fruition & $28.86^{*}$ & $66.75^{\star}$ & 56.00 & 57.00 \\
\hline
\end{tabular}

*Performance.

Table 8. Correlation coefficient (Pearson) among descriptors.

\begin{tabular}{|c|c|c|c|c|c|c|c|c|c|c|c|c|c|c|c|c|}
\hline Parameters & $\mathrm{PH}$ & LL & LB & $\mathrm{PL}$ & ND & NR & HFR & NFPP & TSW & B & NSF & $\mathrm{FL}$ & SGR & FW & DFL & DFR \\
\hline $\mathrm{PH}$ & 1 & & & & & & & & & & & & & & & \\
\hline LI & 0.4552 & 1 & & & & & & & & & & & & & & \\
\hline LB & 0.2578 & $0.8037^{*}$ & 1 & & & & & & & & & & & & & \\
\hline PL & 0.1478 & $0.7069^{*}$ & $0.8839^{*}$ & 1 & & & & & & & & & & & & \\
\hline ND & 0.3909 & 0.3087 & 0.2704 & 0.0413 & 1 & & & & & & & & & & & \\
\hline NR & -0.1653 & 0.1554 & 0.1680 & 0.0817 & 0.3459 & 1 & & & & & & & & & & \\
\hline HFR & 0.4116 & -0.2236 & -0.1565 & -.2870 & 0.1606 & $0-.0083$ & 1 & & & & & & & & & \\
\hline NFPP & -0.2575 & $-0.5029^{*}$ & $-0.6339^{*}$ & $-.7017^{*}$ & -0.2299 & -0.2643 & -0.916 & 1 & & & & & & & & \\
\hline TSW & -0.1993 & 0.2867 & 0.3151 & 0.2562 & -0.0642 & -0.0221 & -0.0851 & 0.2108 & 1 & & & & & & & \\
\hline B & 0.2325 & $0.5237^{*}$ & $0.6681^{*}$ & 0.4141 & 0.4048 & 0.4690 & 0.0928 & -0.3658 & 0.3702 & 1 & & & & & & \\
\hline NSF & -0.2736 & 0.4458 & 0.4866 & $0.5605^{\star}$ & -0.1917 & 0.2159 & -0.2361 & $-0.5001^{*}$ & 0.3434 & 0.2805 & 1 & & & & & \\
\hline $\mathrm{FL}$ & 0.2257 & $0.5214^{*}$ & 0.2857 & 0.3535 & 0.0157 & 0.1361 & -0.0361 & -0.1976 & 0.4571 & 0.2789 & $0.5167^{*}$ & 1 & & & & \\
\hline
\end{tabular}


Table 8. Contd.

\begin{tabular}{|c|c|c|c|c|c|c|c|c|c|c|c|c|c|c|c|c|}
\hline Parameters & $\mathrm{PH}$ & LL & LB & $\mathrm{PL}$ & ND & NR & HFR & NFPP & TSW & B & NSF & $\mathrm{FL}$ & SGR & FW & DFL & DFR \\
\hline SGR & -0.2218 & 0.1932 & 0.2271 & 0.1921 & -0.0330 & 0.2599 & 0.0260 & -0.2454 & 0.4013 & 0.3645 & 0.3821 & 0.3702 & 1 & & & \\
\hline FW & -0.2343 & 0.4167 & 0.4015 & 0.3685 & 0.0259 & 0.4879 & -0.1398 & -0.4661 & 0.0976 & $0.5430^{*}$ & 0.5852 & 0.2535 & 0.3245 & 1 & & \\
\hline DFL & 0.2058 & $0.7157^{*}$ & $0.9319^{*}$ & $0.8266^{*}$ & 0.3296 & 0.3436 & -0.0473 & -0.6154 & 0.3555 & $0.7724^{*}$ & $0.4951^{*}$ & 0.4001 & 0.3907 & 0.4654 & 1 & \\
\hline DFR & 0.2046 & $0.7087^{*}$ & $0.9347^{*}$ & $0.8252^{*}$ & 0.3339 & 0.3330 & -0.0427 & $-0.6159^{*}$ & 0.3498 & $0.7674^{*}$ & $0.4990^{*}$ & 0.3876 & 0.3825 & 0.4572 & $0.9995^{\star}$ & 1 \\
\hline
\end{tabular}

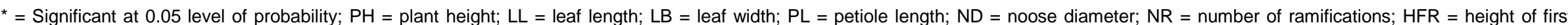

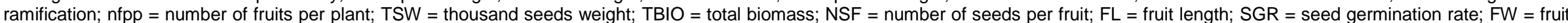
width; DFL = days to flowering and DFR = days to fruiting.

accessions, the use of molecular markers such as AFLPs (Andru et al., 2011) will be necessary as it was the case for many crops such as fonio (Adoukonou et al., 2007), wheat (Altintas et al., 2008), yam (Sonibare et al., 2010) and rice (Rajkumar et al., 2011).

\section{Conclusion}

The agro-morphological characterization of the accessions of $S$. radiatum has contributed to a better assessment of the phenotypes of the collected accessions and an identification of the plants with desired characteristics for breeding. It showed the existence of intra-specific variability. However, it may be necessary to evaluate the characterized accessions over a period of two or more years in many different locations to see if similar observations will be observed. It will be also necessary to enhance the existing germplasm through additional collection from different agro-ecological zones and complete this study by molecular analysis for better assessment of genetic diversity with the species.

\section{ACKNOWLEDGMENTS}

This research was sponsored by the Scientific Council of the University of Abomey-Calavi (UAC) through the collaborative project "6AVG" on traditional leafy vegetable. We also wish to thank anonymous reviewers for their suggestions and constructive criticisms. We are grateful to all the farmers for fruitful discussions during the survey.

\section{REFERENCES}

Abukutsa M (2007). Seed production and support systems fo African leafy vegetables in three communities in western Kenya. Afr. J. Food Agric. Nutr. Dev., 7(3): 16.

Adam S, Boko M (1993). Le Bénin. Les éditions du Flamboyant / EDICEF, Cotonou, République du Bénin, $p$. 96.

Adéoti K, Dansi A, Ahoton L, Kpèki B, Ahohuendo BC Ahanchédé A, Vodouhè R, Hounhouigan JD, Sanni A (2009). Selection of sites for the in situ conservation of fou traditional leafy vegetables consumed in Benin. Int. J. Biol. Chem. Sci., 3(6): 1357-1374

Adomou AC (2005). Vegetation patterns and environmental gradients in Benin: implications for biogeography and conservation. $\mathrm{PhD}$ Thesis, University of Wageningen, Netherlands, p. 136.

Adoukonou H, Wagner C, Dansi A, Ahlemeyer J, Daïnou O, Akpagana K, Ordon F, Friedt W (2007). Genetic diversity and population differentiation of traditional fonio millet (Digitaria spp.) landraces from different agro-ecological zones of West Africa. Theor. Appl. Genet., 115: 917-931.

Akoègninou A, van der Burg WJ, van der Maesen LJG (2006).

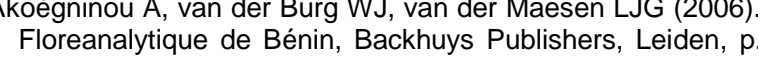
1034

Almekinders C, de Boef W (2000). Encouraging diversity. The conservation and development of plant genetic resources. Intermediate Technology Publication, London (UK). pp. 362 Altintas S, Toklu F, Kafkas S, Kilian B, Brandolini A, Ozkan H
(2008). Estimating Genetic Diversity in Durum and Bread Wheat Cultivars from Turkey using AFLP and SAMPL Markers. Plant Breed., 127(1): 9-14.

Andru S, Pan YB, Thongthawee S, Burner MD, Kimbeng CA (2011). Genetic analysis of the sugarcane (Saccharum spp.) cultivar 'LCP 85-384'. I. Linkage mapping using AFLP, SSR, and TRAP markers. Theor. Appl. Genet., 123(1): 77-93.

Avolio E, Orlandi F, Bellecci C, Fornaciari M, Federico S (2011). Assessment of the impact of climate change on the olive flowering in Calabria (southern Italy). Theoretical and Applied Climatology, DOI: 10.1007/s00704-011-0500-2, Online First.

Bai J, Ge Q, Dai J (2011). The response of first flowering dates to abrupt climate change in Beijing. Adv. Atmos. Sci., 28(3): 564-572.

Chattopadhyay A, Chakraborty K, Dasgupta T, Hazra P, Som M $G$ (1996). Evaluation of genotypes for agronomic and morphological characters in vegetable cowpea. Indian $\mathrm{J}$. morphological charact, 53(4): 321-333.

Hort., 53(4): 321-333.
Chweya JA, Eyzaguirre PB (1999). The biodiversity of traditional leafy vegetables. International Plant Genetic Resources Institute, Rome, Italy, p. 182.

Cilliers AJ, Swanevelder CJ (2003). The South African germplasm collection of groundnut, Arachis hypogea L., and its utility. S. Afr. J. Plant Soil, 20(2): 93-96.

Dansi A, Adjatin A, Adoukonou-Sagbadja $H$, Faladé V, Yedomonhan H, Odou D, Dossou B (2008). Traditional leafy vegetables and their use in the Benin Republic. Genet. Resour. Crop Evol., 55: 1239-1256.

Dansi $A$, Vodouhè $R$, Azokpota $P$, Yedomonhan $H$, Assogba $\mathrm{P}$, Adjatin A, Loko YL, Dossou-Aminon I, Akpagana K (2012). Diversity of the Neglected and Underutilized Crop species of importance in Benin. ID 932947, DOI 10.1100/2012/932947, Sci. World J., p. 19.

Diouf M, Lo C, Gueye M, Mbengue NB (2007). Sélection participative de nouveaux cultivars de quatre (4) espèces de légumes-feuilles (Hibiscus sabdariffaL., AmaranthusL. spp, 
Vignaunguiculata(L.) WALP et MoringaoleiferaLam) au Sénégal. Afri. J. Food Agric. Nutr. Dev., 7(3): 17.

Francisca IS, Eyzaguirre P (2007). African leafy vegetables: their role in the world health organization's global fruit and vegetables initiative. AJFAND., 7(3): 1-17.

Grubben GJH, Denton OA (2004). Plant Resources of Tropical Africa 2. Vegetables. PROTA., p. 668.

IPGRI (2001). Design and analysis of evaluation trials of genetic resources collections.

Kimiywe J, Waudo J, Mbithe D, Maundu P (2007). Utilization and medicinal value of indigenous leafy vegetables consumed in urban and peri-urban Nairobi. Afr. J. Food Agric. Nutr. Dev., 7(4):14.

Konan AB, Datte JY, Yapo PA (2008). Nitric oxide pathway-mediated relaxant effect of aqueous sesame leaves extract (Sesamum radiatum (Schum. amd Thonn) in the guinea-pig isolated aorta smooth muscle. MBC Complement. Altern. Med., 8: 23-30.

Konan BA, Datté JY, Offoumou AM (2006). Action of the aqueous extract of Sesamumradiatum Schum.\&Thonn. (Pedaliaceae) on the cardiovascular system of mammalians: Hypotensive effect. Curr. Bioactive Comp., 2: 263-267.

Maundu PM, Njiro El, Chweya JA, Imungi JK, Seme EN (1999). The bioversity of traditional leafy vegetables in Kenya. In: Chweya JA and Eyzaguirre PB (eds), (1999). The biodiversity of traditional leafy vegetables. International Plant Genetic Resources Institute, Rome, Italy, pp. 51-83.

Mbaye A, Moustier P (2000). Market-oriented urban agricultural production in Dakar.In:Bakker $\mathrm{N}$ et al. (eds) Growing cities, growing food: urban agriculture on the policy agenda, a reader on urban agriculture, Feldafing, Allemangne.

Mih MA, Tonjock KR, Ndam LM (2008). Morphological characterization of four selections of Vernonia hymenolepsis A. Rich. (Asteraceae). World J. Agric. Sci., 4(2): 220-223.

Musvosvi C (2009). Morphological characterisation and interrelationships among descriptors in some cowpea genotypes. Afr. Crop Sci. Conf. Proc., 9: 501-507.

Ogunlesi M, Okiei W, Osibote EA (2010). Analysis of the essential oil from the leaves of Sesamumradiatum, a potential medication for male infertility factor, by gas chromatography - mass spectrometry. Afr. J. Biotechnol., 9(7): 1060-1067.
Rajkumar G, Weerasena J, Fernando K, Liyanage A (2011). Assessment of genetic diversity among Sri Lankan rice varieties by AFLP markers. Plant Genet. Resour., 9(2): 224-228.

Sarutayophat T, Nualsri C, Santipracha Q, Saereeprasert V (2007). Characterization and genetic relatedness omong 37 yardlong bean and cowpea accessions based on morphological characters and RAPD analysis.Songklanakarin. J. Sci. Technol., 29(3): 591-600.

SAS Institute (1999). SAS (Statistical Analysis System) user's guide: statistic. SAS Institute, NC.

Schippers RR (2002). African Indigenous Vegetables: an Overview of the Cultivated Species 2002-Revised version on CD-ROM. Natural Resources International Limited, Aylesford, UK.

Sheela MS, Gopalan A (2006). Association studies for yield and its related traits of fodder cowpea in F4 generation. J. Appl. Sci. Res., 2(9): $584-586$.

Shittu LAJ, Bankole MA, Ahmed T, Aile K, Akinsanya MA, Bankole MN, Shittu RK, Ashiru OA (2006). Differential antimicrobial activity of the various crude leaves extracts of Sesamum radiatum against some common pathogenic micro-organisms. Sci. Res. Essay, 1(3): 108111.

Shittu LAJ, Bankole MA, Oguntola JA, Ajala O, Shittu RK, Ogundipe OA, Bankole MN, Ahmed T, Ashiru OA (2007). Sesame leaves intake improves and increases epididymal spermatocytes reserve in adult male Sprague Dawley rat. Sci. Res. Essay, 2(8): 319-324.

Sneath PHA, Sokal RO (1973). Numerical taxonomy, Freeman, San Francisco.

Sonibare MA, Asiedu R, Albach DC (2010). Genetic diversity of Dioscorea dumetorum (Kunth) Pax using Amplified Fragment Length Polymorphisms (AFLP) and cpDNA. Biochem. Syst. Ecol., 38(3): 320-334

Swofford DL, Olsen GJ (1990). Phylogeny reconstruction.In Hillis D.M., Moritz C., (eds.) Molecular systematic.Sinauer Associates, Sunderland, pp. 411-501.

Vodouhè R, Dansi A, Avohou HT, Kpèki B, Azihou F (2011). Plant domestication and its contributions to in situ conservation of genetic resources in Benin. Int. J. Biodivers. Conserv., 3(2): 40-56. 